\title{
SEX, SOCIO-ECONOMIC STATUS, AND SECULAR INCREASE IN STATURE
}

\section{A FAMILY STUDY}

\author{
BY \\ ROY M. ACHESON AND GILLIAN B. FOWLER* \\ From the Medical Schools of Guy's Hospital, London, and Yale University, New Haven, Conn.
}

The evidence that each succeeding generation of children in Western Europe is taller than its predecessor has been accumulating (Boyne and Leitch, 1954; Hulse, 1957; Boyne, 1960; Tanner, 1962) and the question has been raised whether this phenomenon is primarily due to improvement of the environment during childhood, or to heterosis (British Medical Journal, 1961). If, as we believe, environment plays an important part in the secular increase in stature, then the extent to which children are taller than their parents should be related to the material benefits enjoyed by these children which were not available to their parents. The present paper describes a study in which the stature of men, women, and their children from the Rhondda Fach in South Wales is compared with that of London families in the upper income groups. The Welsh parents, for some or all of their childhood, were exposed to the privations of the economic depression of $1930 \mathrm{~s}$, but their children were born in more prosperous times since 1945 . In contrast, the parents in the London sample did not suffer unduly in the late 1920 s and 1930 s and their children too enjoyed relative prosperity.

Our working hypothesis was, then, that the between-generation difference in stature in the Welsh group should be greater than that in the Londoners.

\section{Material AND Methods}

152 families were invited to participate in this study; 119 were drawn from the Medical Research Council's census of the Rhondda Fach (Cochrane, Cox, and Jarman, 1952, 1955), and 33 were the families of boys or staff members at St. Paul's School, Hammersmith, London. The Welsh sample,

* Present address of both authors: Department of Epidemiology and Public Health, Yale University School of Medicine, 333 Cedar Street, New Haven 11, Conn. which consisted of families in which the parents were living together and at least one child was aged between 2 and 14 years, was drawn in two parts. The first, selected in 1960, was taken from the entire population of the Rhondda Fach (some 20,000 people) and consisted of 25 families of men who were employed as miners at the time of the 1958 MRC census, and 25 families of men who were in professional or commercial occupations at that time. The second sample, selected in 1961, consisted of the families of all the men who were working at the coalface in 1958 and were resident in an area delineated by us on the map at the lower end of the valley. The London families, in which the fathers were all professional or business men, were selected in an arbitrary manner by a senior member of the teaching staff of St. Paul's School and are in no way a random sample. Every effort was made to persuade the Welsh people to co-operate. The Londoners were invited to participate by letter but it was not possible to apply any further coercion to those who refused this written invitation. The number of families in these three groups and the levels of co-operation are set out in Table I.

TABLE I

CO-OPERATION OF FAMILIES IN THREE ORIGINAL SAMPLES

\begin{tabular}{l|c|c|c}
\hline \multicolumn{1}{c|}{ Group } & \multicolumn{1}{c|}{$\begin{array}{c}\text { No. of } \\
\text { Families } \\
\text { in Sample }\end{array}$} & \multicolumn{2}{|c}{$\begin{array}{c}\text { Families } \\
\text { which } \\
\text { Co-operated }\end{array}$} \\
\cline { 4 - 5 } & & No. & Per cent. \\
\hline St. Paul's School .. & 33 & 24 & 73 \\
First Welsh sample .. & 50 & 41 & 82 \\
Second Welsh sample... & 69 & 60 & 87 \\
\hline Total .. & 152 & 125 & 82 \\
\hline
\end{tabular}

A study of the occupational history of the Welsh families showed that, although some men were not working in the mines at the time of the 1958 census, 
they had spent the greater part of their lives working manually in the coal industry. Since we were interested in weighing environmental factors throughout the children's lives, we decided to reclassify the first Welsh sample, taking into account the grandfathers' occupations as well as the fathers' long-term occupational history. This approach led us to classify 89 of the Welsh families as coming from a predominantly mining background, and only nine as being of professional and commercial status. Three of the families did not come into either group and were excluded from the analysis.

Table II shows the number of families in the three groups: London (X), Welsh Commercial and Professional (Y), and Coalminers (Z).

TABLE II

NUMBER OF FAMILIES IN EACH OF THREE SOCIOECONOMIC GROUPS

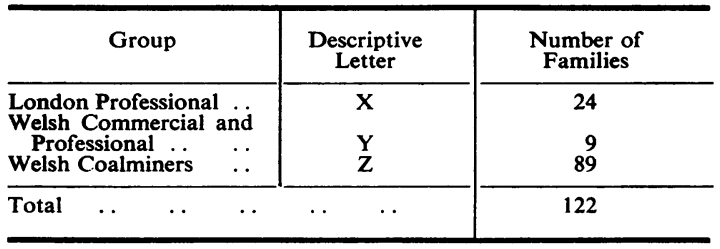

Table III shows the total number of children in the families and the proportion who were measured. Although the co-operation of the London families was the poorest $(73 \%)$, the level of participation of children within these families was highest $(98 \%)$. In contrast, over 80 per cent. of the miners allowed us to study their families, but we measured only 91 per cent. of their children because many of the older siblings had emigrated from the valley. The average family size in all three groups was about $2 \frac{1}{2}$ children aged 2 years and over.

TABLE III

CO-OPERATION OF CHILDREN, BY FAMILY AND SOCIOECONOMIC GROUP

\begin{tabular}{c|c|c|c|c}
\hline \multirow{2}{*}{ Group } & \multicolumn{3}{|c|}{ Children } & $\begin{array}{c}\text { Per cent. } \\
\text { co- } \\
\text { operation }\end{array}$ \\
\cline { 2 - 4 } & Seen & Not seen & Total & X \\
\hline Y & 64 & 1 & 65 & 98 \\
Z & 21 & 2 & 23 & 91 \\
\hline Total $\quad \cdots$ & 296 & 22 & 233 & 91 \\
\hline
\end{tabular}

The London children were older on average than either of the Welsh groups (Table IV); it is also clear that the London group contained a disproportionate number of boys.

Both parents and each co-operating son and daughter over the age of 2 years were studied; of several observations made, only the standing height,
TABLE IV

MEAN CHRONOLOGICAL AGE (MTHS) OF CHILDREN IN THE THREE GROUPS, BY SEX

\begin{tabular}{c|c|c|c|c|c|c}
\hline \multirow{2}{*}{ Group } & \multicolumn{3}{|c|}{ Boys } & \multicolumn{3}{c}{ Girls } \\
\cline { 2 - 6 } & No. & $\begin{array}{c}\text { Mean } \\
\text { Age (mths) }\end{array}$ & S.D. & No. & $\begin{array}{c}\text { Mean } \\
\text { Age (mths) }\end{array}$ & S.D. \\
\hline $\mathbf{X}$ & 47 & $183 \cdot 66$ & $55 \cdot 31$ & 17 & $153 \cdot 76$ & $54 \cdot 74$ \\
$\mathbf{Y}$ & 12 & $104 \cdot 92$ & $61 \cdot 78$ & 9 & $127 \cdot 11$ & $63 \cdot 23$ \\
$\mathrm{Z}$ & 101 & $140 \cdot 26$ & $63 \cdot 55$ & 110 & $143 \cdot 16$ & $71 \cdot 70$ \\
\hline
\end{tabular}

measured by the method of Falkner (1960), and an antero-posterior radiograph of the left hand and wrist are pertinent to this paper. The latter were assessed for skeletal age independently by both of us, using the Atlas of Greulich and Pyle (1959), and the two readings were averaged. The probable adult height of growing children was predicted from present height and skeletal age using the tables of Bayley and Pinneau (1952), a procedure carrying a considerable potential error (Acheson, Fowler, Fry, Janes, Koski, Urbano, and Werff ten Bosch, 1963).

Many of the Welsh children were measured again one or two years later but, except for the analysis in Table XI (below, p. 30), only the measurements made at the first interview were used in this analysis.

\section{FINDINGS}

Skeletal Maturity and Socio-economic Class

Skeletal age is a system devised for measuring skeletal maturity, and the scale is so constructed that its relationship with chronological age is rectilinear* (Todd, 1937; Greulich and Pyle, 1959; Hewitt and Acheson, 1961). It was therefore possible to compare the three groups $\mathrm{X}, \mathrm{Y}$, and $\mathrm{Z}$, and at the same time to allow for differences in the maturity status of the children by using a simple regression analysis.

TABLE $\mathrm{V}$

REGRESSION OF SKELETAL AGE ON CHRONOLOGICAL AGE FOR BOYS UNDER 19⿺辶寸 YEARS AND GIRLS UNDER AGE 18 YEARS, BY SOCIO-ECONOMIC GROUP

\begin{tabular}{|c|c|c|c|c|c|c|c|c|}
\hline \multirow{2}{*}{ Group } & \multicolumn{4}{|c|}{ Boys } & \multicolumn{4}{|c|}{ Girls } \\
\hline & No. & $a$ & $\boldsymbol{b}$ & s.e.(b) & No. & $a$ & $b$ & s.e.(b) \\
\hline $\begin{array}{l}\mathbf{X} \\
\mathbf{Y} \\
\mathbf{Z}\end{array}$ & $\begin{array}{l}42 \\
12 \\
92\end{array}$ & $\begin{array}{r}0.32 \\
-12.08 \\
-1 \cdot 80\end{array}$ & $\begin{array}{l}0.987 \\
1.076 \\
0.968\end{array}$ & $\begin{array}{l}0.041 \\
0.050 \\
0.026\end{array}$ & $\begin{array}{r}15 \\
9 \\
92\end{array}$ & $\begin{array}{r}-6.54 \\
-3.09 \\
-2.64\end{array}$ & $\begin{array}{l}1.001 \\
0.997 \\
0.973\end{array}$ & $\begin{array}{l}0.065 \\
0.046 \\
0.026\end{array}$ \\
\hline
\end{tabular}

For significance of these differences see Table VII

* The technique used for constructing this scale was, in general principle, to $x$-ray the hands of a group of healthy boys and girls on or near their birthday, year after year; then, for each age group and each sex, to array the films in order of increasing maturity, and take each sex, to array the films in order of increasing maturity, and take
the median film in each array as being a standard for that age and sex. In 5 -year-old boys, this standard would be named skeletal age 5 years, and so on. Thus, in a normal child, for each unit increase in skeletal maturity on such a scale, there is an equal increase in age on an identical scale and the relationship between the two is rectilinear. 

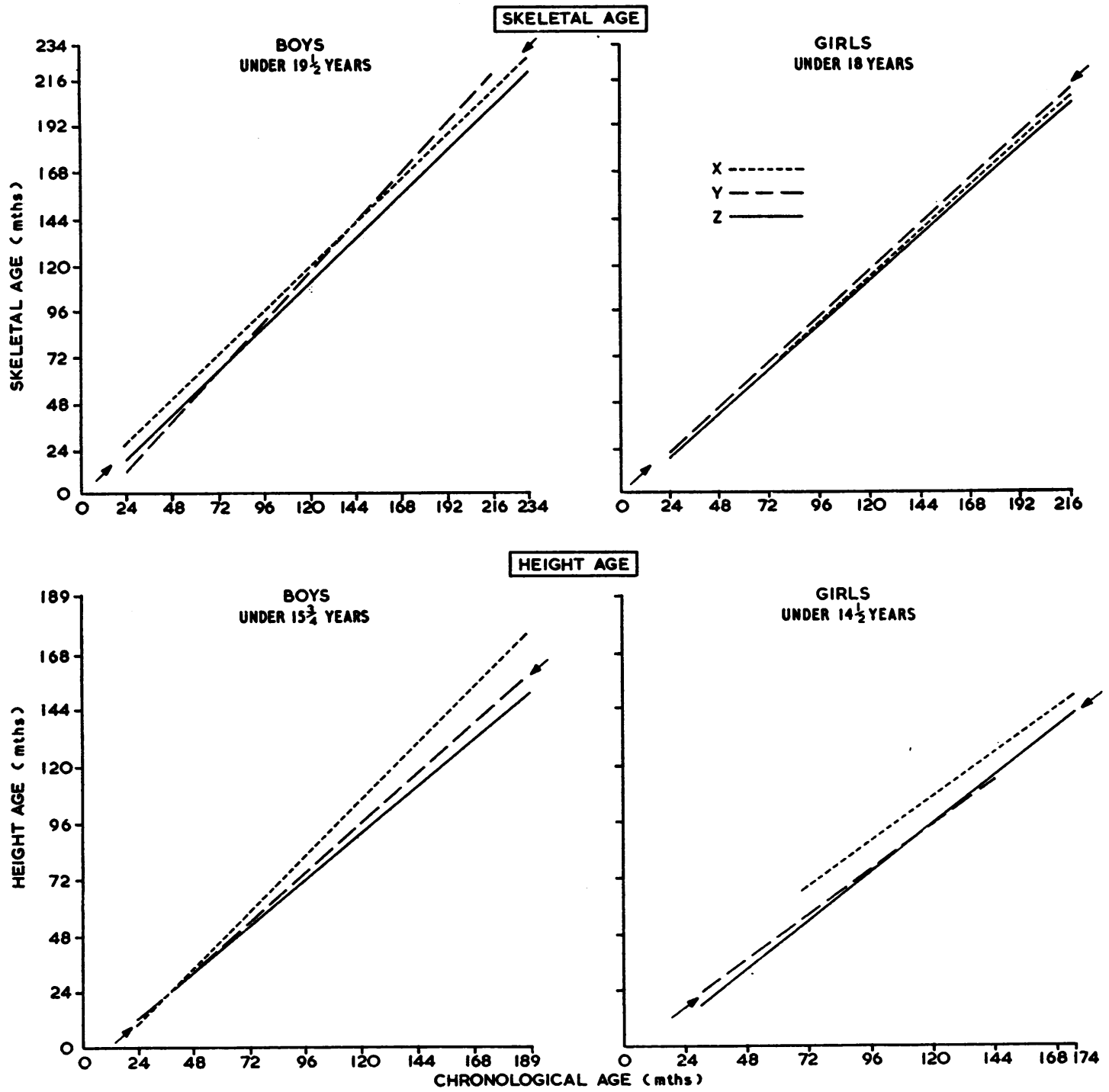

Fig. 1.-Regressions of skeletal age on chronological age for boys under $19 \frac{1}{2}$ years and girls under 18 years, and of height age on chronological age for boys under $15 \frac{3}{2}$ years and girls under $14 \frac{1}{2}$ years, for the three socio-economic groups, $X, Y$, and $Z$.

The results are shown in Fig. 1 and in Table $\mathrm{V}$ (opposite), where column $a$ represents the intercept and $b$ the regression coefficient. Boys aged $19 \frac{1}{2}$ years and over and girls aged 18 and over were omitted from this analysis because it was found that by these ages all the children studied had mature hands and that therefore no further increase in skeletal age was to be expected with increasing chronological age. For boys the $\mathrm{X}$ group is more mature at all ages than the $Z$ group, but these differences are not significant (column $a$, Table VII, overleaf); the regression for $Y$ group boys cuts the other two lines (Fig. 1), but does not differ significantly from them (column $b$, Table VII). There are no differences of note between the girls in the three groups. 


\section{Stature and Socio-economic Class}

Standardization of stature for difference in age was achieved by two different techniques. The first involved the use of the concept of "height age",* and the second the prediction of adult height from present height using the tables of Bayley and Pinneau (1952).

Height Age.-This is a concept which in our opinion can be misleading in the clinict, but is useful for present purposes because, between the ages of 2 and less than $14 \frac{1}{2}$ years for girls and 2 and less than $15 \frac{3}{4}$ years for boys, its relationship with chronological age is rectilinear, or almost rectilinear. Therefore it was again possible, using a regression analysis, to take children of differing stature and age into account at the same time. The analysis (Table VI and Fig. 1)

\section{TABLE VI}

REGRESSION OF HEIGHT AGE ON CHRONOLOGICAL AGE

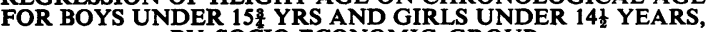
BY SOCIO-ECONOMIC GROUP

\begin{tabular}{|c|c|c|c|c|c|c|c|c|}
\hline \multirow{2}{*}{ Group } & \multicolumn{4}{|c|}{ Boys } & \multicolumn{4}{|c|}{ Girls } \\
\hline & No. & $a$ & $b$ & s.e.(b) & No. & $a$ & $b$ & s.e.(b) \\
\hline $\begin{array}{l}\mathbf{X} \\
\mathbf{Y} \\
\mathbf{Z}\end{array}$ & $\begin{array}{l}24 \\
11 \\
82\end{array}$ & $\begin{array}{r}-10 \cdot 70 \\
-6 \cdot 91 \\
-6 \cdot 11\end{array}$ & $\begin{array}{l}0.992 \\
0.877 \\
0.837\end{array}$ & $\begin{array}{l}0.064 \\
0.064 \\
0.028\end{array}$ & $\begin{array}{r}11 \\
6 \\
83\end{array}$ & $\begin{array}{r}12 \cdot 21 \\
-2.98 \\
-9.94\end{array}$ & $\begin{array}{l}0 \cdot 787 \\
0 \cdot 823 \\
0 \cdot 872\end{array}$ & $\begin{array}{l}0.077 \\
0.053 \\
0.025\end{array}$ \\
\hline
\end{tabular}

For significance of these differences see Table VII

* "Height age" was calculated from the 97th percentile of the Tanner-Whitehouse standards for stature (for description see Tanner, 1958; Tanner and Whitehouse, 1959). This percentile was chosen because many of the older $X$ children were outside the entire range of the 50 th percentile and the 97 th alone contained all the children. The procedure followed was to ascertain the age at which each child would, were it on the 97 th percentile, achieve its present height, and to were it on the 97 th percentile, achieve its present height, and to stressed that the 97 th percentile is not rectilinear throughout its course stressed that the 97th percentile is not rectilinear throughout its course
and that therefore simple regressions can only be used between the ages of 2 and $14 \frac{1}{2}$ for girls, and 2 and $15 \%$ for boys.

† In these terms a small but quite healthy child of 11 may be described as having a "height age" of 9 years, thereby falsely implying a considerable degree of retardation. shows that, for boys and girls, the children in the $\mathrm{X}$ group tended to be taller at all ages than the children of the other two groups. These differences were significant $(\mathrm{P}<0 \cdot 001)$ (column $a$, Tables VI and VII) for the comparison between the $\mathrm{X}$ and $\mathrm{Z}$ groups, but not for the comparison between the $X$ and the numerically small $Y$ group. The slopes $(b)$ of the three regressions for height age of boys also differed, so that $b$ was greatest for the $\mathrm{X}$ group and smallest for the $Z$ group with $Y$ intermediate. Again, a measure of the growth of $X$ was significantly greater than the same measure for $Z$, but that for $Y$ did not differ significantly from the others; details of these probabilities are given in Table VII. The implication of this finding is that the more prosperous the home background of a boy the more rapid is his growth. There was no similar suggestion of differences in the growth rates of the girls.

Predicted Adult Height.-The prediction of adult height from the Bayley-Pinneau Tables assumes (1) that the rate of growth will remain constant in relation to the rate of skeletal maturation from the time the prediction is made until growth ceases, (2) that the inter-relationship between these two processes will be the same as it was in the group of healthy American children, on whose development the Tables are based.

These are considerable assumptionst but Table VIII (opposite) shows that the predictions for each of the socio-economic groups are strikingly similar to the actual adult heights of the elder siblings in the families whose hand $x$ rays indicated they were skeletally mature. Therefore actual and predicted adult heights will be combined in ensuing analyses.

$\ddagger$ The reliability of assessing skeletal age is considered in the Discussion (below).

TABLE VII

PROBABILITY VALUES OF THE DIFFERENCES BETWEEN STATISTICS SHOWN IN TABLES V AND VI

\begin{tabular}{|c|c|c|c|c|c|c|c|c|}
\hline \multirow{3}{*}{ Comparison } & \multicolumn{4}{|c|}{ Skeletal Age } & \multicolumn{4}{|c|}{ Height Age } \\
\hline & \multicolumn{2}{|c|}{ Boys } & \multicolumn{2}{|c|}{ Girls } & \multicolumn{2}{|c|}{ Boys } & \multicolumn{2}{|c|}{ Girls } \\
\hline & $a$ & $b$ & $a$ & $b$ & $\bar{a}$ & $\boldsymbol{b}$ & $a$ & $\boldsymbol{b}$ \\
\hline $\begin{array}{l}X \text { and } Y \\
X \text { and } Z \\
Y \text { and } Z\end{array}$ & $<\overline{0} \cdot 1$ & $\begin{array}{l}<0.4 \\
>0.5 \\
<0.1\end{array}$ & $>\overline{0.5}$ & $\begin{array}{l}>0.5 \\
>0.5 \\
>0.5\end{array}$ & $<\overline{0.001}$ & $\begin{array}{l}<0.4 \\
<0.01 \\
>0.5\end{array}$ & $<\overline{0.001}$ & $\begin{array}{l}>0.5 \\
<0.4 \\
>0.5\end{array}$ \\
\hline
\end{tabular}

Comparisons between regression coefficients were made with Student's " $t$ " test. Those between $a$ values are based on an estimate of the difference between actual skeletal or height age at any chronological age and the value expected on the basis of a regression common to the two groups concerned. These values were only calculated for the $\mathbf{X}$ and $\mathrm{Z}$ comparisons. Inspection of Fig. 1 shows that the other comparisons do not approach significance. 
TABLE VIII

STANDING HEIGHT OF FULLY-GROWN CHILDREN AND PREDICTED ADULT HEIGHT OF GROWING CHILDREN, BY SEX AND SOCIO-ECONOMIC GROUP

\begin{tabular}{|c|c|c|c|c|c|c|c|c|c|c|c|c|}
\hline \multirow{3}{*}{ Group } & \multicolumn{6}{|c|}{ Boys } & \multicolumn{6}{|c|}{ Girls } \\
\hline & \multicolumn{3}{|c|}{$\begin{array}{c}\text { Grown- } \\
\text { actual } \\
\text { Stature }\end{array}$} & \multicolumn{3}{|c|}{$\begin{array}{l}\text { Growing- } \\
\text { predicted } \\
\text { Stature }\end{array}$} & \multicolumn{3}{|c|}{$\begin{array}{c}\text { Grown- } \\
\text { actual } \\
\text { Stature }\end{array}$} & \multicolumn{3}{|c|}{$\begin{array}{l}\text { Growing- } \\
\text { predicted } \\
\text { Stature }\end{array}$} \\
\hline & No. & Mean & S.D. & No. & Mean & S.D. & No. & Mean & S.D. & No. & Mean & S.D. \\
\hline $\begin{array}{l}\mathbf{X} \\
\mathbf{Y} \\
\mathbf{Z}\end{array}$ & $\frac{8}{9}$ & $\frac{71 \cdot 3}{67 \cdot 6}$ & $\frac{1 \cdot 2}{2 \cdot 8}$ & $\begin{array}{r}36 \\
6 \\
72\end{array}$ & $\begin{array}{l}71 \cdot 8 \\
69 \cdot 6 \\
68 \cdot 5\end{array}$ & $\begin{array}{l}2 \cdot 7 \\
1 \cdot 5 \\
2 \cdot 3\end{array}$ & $\begin{array}{r}-1 \\
16\end{array}$ & $\begin{array}{l}\overline{65 \cdot 9} \\
62 \cdot 6\end{array}$ & $\bar{z}$ & $\begin{array}{r}15 \\
5 \\
76\end{array}$ & $\begin{array}{l}65 \cdot 6 \\
63 \cdot 6 \\
62 \cdot 9\end{array}$ & $\begin{array}{l}2 \cdot 1 \\
2 \cdot 8 \\
2 \cdot 1\end{array}$ \\
\hline
\end{tabular}

Table IX shows the adult heights of the children, actual or predicted, as the case may be, by socioeconomic class and sex, as well as the standing heights of their parents (see also Fig. 2).

For both generations there is a gradient in stature, so that the most prosperous are the tallest and those with the lowest socio-economic status the shortest, the Welsh professional and commercial group taking an intermediate position.

The differences between the extreme groups ( $\mathrm{X}$ and $Z$ ) for both sexes and both generations are highly significant (Table $\mathrm{X}$ ); the Welsh professional and commercial fathers are also significantly taller than the miners $(\mathrm{P}<0 \cdot 01)$.

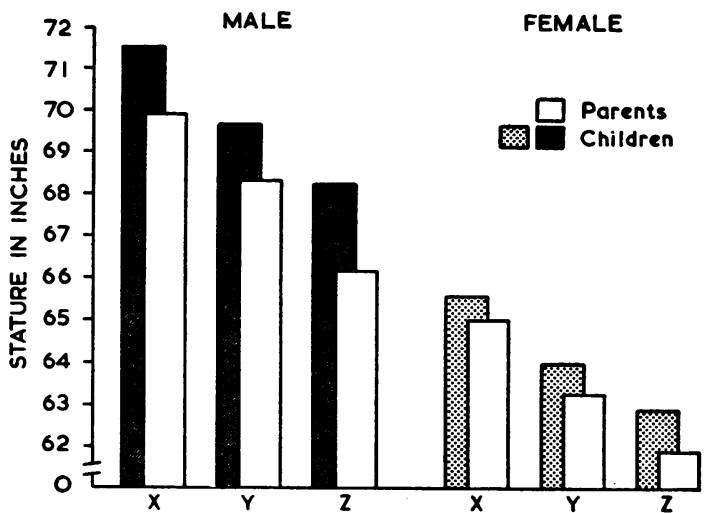

FIG. 2.-Mean adult stature (actual or predicted) in inches of parents and children by sex and socio-economic group. For number of subjects in each histogram bar, see Table IX.

TABLE IX

PREDICTED AND ACTUAL ADULT STATURE (in.) OF THE CHILDREN AND THE STATURE OF THEIR PARENTS, BY SEX AND SOCIO-ECONOMIC GROUP

\begin{tabular}{|c|c|c|c|c|c|c|c|c|c|c|c|c|}
\hline \multirow{3}{*}{ Group } & \multicolumn{6}{|c|}{ Male } & \multicolumn{6}{|c|}{ Female } \\
\hline & \multicolumn{3}{|c|}{ Son } & \multicolumn{3}{|c|}{ Father* } & \multicolumn{3}{|c|}{ Daughter } & \multicolumn{3}{|c|}{ Mother* } \\
\hline & No. & Mean & S.D. & No. & Mean & S.D. & No. & Mean & S.D. & No. & Mean & S.D. \\
\hline $\begin{array}{l}\mathbf{X} \\
\mathbf{Y} \\
\mathbf{Z}\end{array}$ & $\begin{array}{r}44 \\
6 \\
81\end{array}$ & $\begin{array}{l}71 \cdot 7 \\
69 \cdot 6 \\
68 \cdot 4\end{array}$ & $\begin{array}{l}2 \cdot 5 \\
1 \cdot 5 \\
2 \cdot 4\end{array}$ & $\begin{array}{r}24 \\
9 \\
88\end{array}$ & $\begin{array}{l}69 \cdot 9 \\
68 \cdot 4 \\
66 \cdot 3\end{array}$ & $\begin{array}{l}2 \cdot 5 \\
1.9 \\
2 \cdot 2\end{array}$ & $\begin{array}{r}15 \\
6 \\
92\end{array}$ & $\begin{array}{l}65 \cdot 6 \\
64 \cdot 0 \\
62 \cdot 8\end{array}$ & $\begin{array}{l}2 \cdot 1 \\
2 \cdot 7 \\
2 \cdot 1\end{array}$ & $\begin{array}{r}24 \\
9 \\
89\end{array}$ & $\begin{array}{l}65 \cdot 1 \\
63 \cdot 4 \\
61 \cdot 9\end{array}$ & $\begin{array}{l}2 \cdot 4 \\
2 \cdot 7 \\
2 \cdot 2\end{array}$ \\
\hline
\end{tabular}

Probability values for these differences are given in Table $\mathbf{X}$.

* The mean ages of the fathers and mothers of the $X$ group were not more than 5 years more than those of the $Z$ group. The operation of the secular trend for the increase in stature with later date of birth would, if anything, exaggerate the stature differences between these two groups.

TABLE X

PROBABILITY VALUES OF THE DIFFERENCES BETWEEN THE MEANS SHOWN IN TABLE IX

\begin{tabular}{|c|c|c|c|c|c|c|c|c|}
\hline \multirow{3}{*}{ Comparison } & \multicolumn{4}{|c|}{ Male } & \multicolumn{4}{|c|}{ Female } \\
\hline & \multicolumn{2}{|c|}{ Son } & \multicolumn{2}{|c|}{ Father } & \multicolumn{2}{|c|}{ Daughter } & \multicolumn{2}{|c|}{ Mother } \\
\hline & “t" & $\mathbf{P}$ & "t" & $\mathbf{P}$ & "t" & $\mathbf{P}$ & “t”" & $\mathbf{P}$ \\
\hline $\begin{array}{l}X \text { and } Y \\
X \text { and } Z \\
Y \text { and } Z\end{array}$ & $\begin{array}{l}1.98 \\
7.39 \\
1 \cdot 29\end{array}$ & $\begin{array}{l}<0.1 \\
<0.001 \\
<0.3\end{array}$ & $\begin{array}{l}1 \cdot 63 \\
6 \cdot 81 \\
2 \cdot 70\end{array}$ & $\begin{array}{l}<0.2 \\
<0.001 \\
<0.01\end{array}$ & $\begin{array}{l}1.49 \\
4.79 \\
1.30\end{array}$ & $\begin{array}{l}<0.2 \\
<0.001 \\
<0.2\end{array}$ & $\begin{array}{l}1 \cdot 75 \\
6 \cdot 15 \\
1 \cdot 87\end{array}$ & $\begin{array}{l}<0.1 \\
<0.001 \\
<0.1\end{array}$ \\
\hline
\end{tabular}

Degrees of freedom for " $t$ " can be readily calculated from the numbers given in Table IX 
Stature Difference between Generations AND SOCIO-ECONOMIC Class

Table IX also shows that in each socio-economic group the children are, or are predicted to become, taller than their parents of the same sex. This between-generation difference in stature was studied in more detail (Table XI and Fig. 3).

\section{TABLE XI}

EXCESS OF MEAN STATURE (ACTUAL AND PREDICTED) OF ALL CHILDREN OF ONE SEX IN EACH FAMILY OVER THAT OF THE PARENT OF THE SAME SEX (in.)

\begin{tabular}{|c|c|c|c|c|c|c|}
\hline \multirow{2}{*}{ Group } & \multicolumn{3}{|c|}{ Male } & \multicolumn{3}{|c|}{ Female } \\
\hline & $\begin{array}{l}\text { Excess } \\
\text { Stature }\end{array}$ & No. & $\mathbf{P}$ & $\begin{array}{l}\text { Excess } \\
\text { Stature }\end{array}$ & No. & $\mathbf{P}$ \\
\hline $\begin{array}{l}\mathbf{X} \\
\mathbf{Y} \\
\mathbf{Z}\end{array}$ & $\begin{array}{l}1 \cdot 9 \\
1 \cdot 8 \\
2 \cdot 3\end{array}$ & $\begin{array}{r}22 \\
7 \\
56\end{array}$ & $\begin{array}{l}<0.001 \\
<0.02 \\
<0.001\end{array}$ & $\begin{array}{r}0.3 \\
-0.6 \\
1.0\end{array}$ & $\begin{array}{r}12 \\
6 \\
63\end{array}$ & $\begin{array}{l}>0.5 \\
>0.5 \\
<0.001\end{array}$ \\
\hline
\end{tabular}

The between-generation difference for males is significantly greater than that for females in the $X$ and $Z$ groups $(P \bumpeq 0.01)$, but not for the $Y$ group. Within each sex no socio-economic group differs significantly from another.

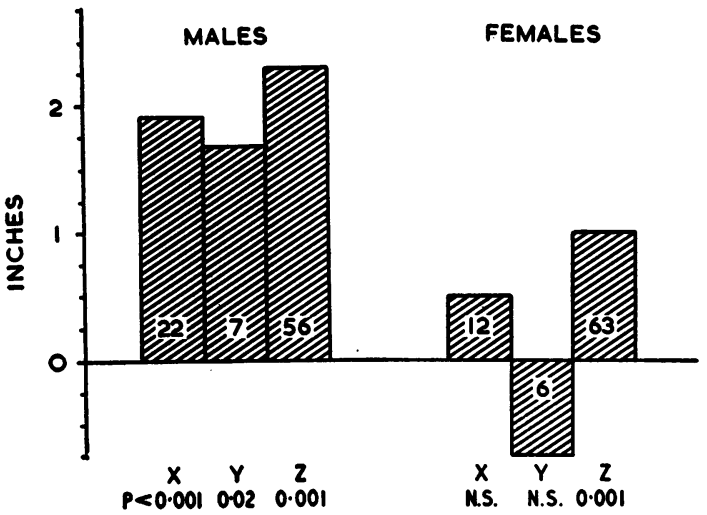

Fig. 3.-Mean excess of adult stature (actual or predicted) of children over that of the parent of the same sex, by sex and socio-economic class, corrected for family size. See text footnote * below.

The excess stature (or predicted stature) of each child over its parent of the same sex was computed, the sex-specific mean for each family calculated, and the results presented separately for the two sexes and for each socio-economic class.* It can be seen that the differences are greatest in Group $Z$ and that, whereas all groups of boys are significantly taller than their fathers, only the miners' daughters are significantly taller than their mothers. Thus the between-sex discrepancy which exists in the stature

* The numbers in Table XI are smaller than those in Table IX, because the former gives the number of families with sons or daughters foc whom data on actual or predicted adult height is available, whilst for whom data on actual or predicted adult height is available, whilst the latter gives information on each individual child. It was necessary the genetic contribution from each family is the same, regardless of the number of sons and daughters. of the parent generation will be even greater in the children when they grow up.

\section{Discussion}

The results shown in Table XI and Fig. 3 would seem to be consistent with our working hypothesis but, before accepting them, we must carefully consider such matters as the validity of the sample, and in more detail the precision and the accuracy of predictions of adult height.

The SAMPLE-The fact that part of our sample lives in Wales and part in England naturally raises the objection that any differences observed may be racial and not environmental in origin-although many of the mining families in the lower Rhondda Fach migrated there from south western England before the first world war. In an attempt to discover whether there is a systematic difference in stature between persons of the same social class in England and Wales we compared the standing height of men and women in the Rhondda Fach and the Vale of Glamorgan $\uparrow$ with measurements made by one of us (G.B.F.) of the stature of a random sample of persons who co-operated in a survey of glycosuria in Bedford in 1962. It was only for the Registrar General's Social Classes II and III in the male ane III in the female that these differences are significan at the 5 per cent. level or less. When the five sociaf classes were pooled on a sex-specific basis, for ages 20 to 79 years, the English stature exceeded the Welsh on average by $0.76^{\prime \prime}$ for men and $0.85^{\prime \prime}$ for women. These are similar to the findings of Martin (1949) and amount to about one-third of the total (X-Z) differences (refer to Table IX), leaving twothirds of these differences to be explained by "non-racial" factors.

\section{Prediction of Adult Height}

There are three possible sources of error in the prediction of adult height. The first, and most trivial, is the measurement of the standing height of the child. We used the technique and equipment accepted by the International Children's Centre for co-ordinated growth studies in seven different countries (Falkner, 1960), which give in experienced hands repeatability to within a fraction of an inch.

Skeletal age assessments are not, however, nearly so accurate. Acheson and others (1963) estimate that the 95 per cent. confidence limits of the assessment of a single film by a single observer are roughly \pm 10 skeletal months when films known to be difficult

t These were calculated by us from unpublished data collected by Dr. W. E. Miall in his studies of blood pressure (see Miall and Oldham, 1955, 1963). 
are being studied. If two readers assess the films independently, however, and the two readings are averaged these limits are reduced to \pm 7 skeletal months.* In terms of predicted adult height, an error of this magnitude could at certain critical stages of pre-pubertal development mean $\pm 1 \frac{1}{2}^{n}$ in stature estimate of either sex, but after puberty it would not exceed $\pm \frac{1}{2}$ " for boys or girls. Provided, however, any such errors in this study are random, and we have every reason to believe they are, both in respect of the age of the child and of the socioeconomic class to which he belongs, they will not distort our findings.

The third possible source of error, which has been referred to above, lies in the tables themselves. By using the Bayley-Pinneau data, we have made several tacit assumptions: e.g. (1) that similar relationships exist between the growth and maturation of the two populations we have studied as those which obtain for the American children on whom the standards are based; (2) that there is no bias within the standards themselves which systematically influences the predictions for one sex or age group in one direction and those for the other sex or a different age group in another. Tanner (1962) reviews in detail knowledge which underlies the first assumption, and although there are unquestionably factors which do alter growth curves between one population and another, we do not believe that these have affected our findings significantly. However, as Doll (1959) has pointed out, possibly the most sensitive indicator of spurious findings in a survey is internal inconsistency. Not only are our results consistent with our hypothesis, but they are consistent with each other and-as we will develop in more detail below-with the generally accepted effects of environment upon physical development.

\section{Physical Development and Socio-economic Status}

Our sample was picked in such a way that for both generations the $X$ group enjoyed a higher standard of living than the $\mathrm{Z}$ group; in addition the standard of living between the first and second generation improved a great deal for the $\mathrm{Z}$ group, but there was no such marked improvement for the $X$ group. The differences in stature and growth of the children from the $\mathrm{X}$ and $\mathrm{Z}$ groups (Table VI) and of the stature of their parents (Table IX) is consistent with the known relationships between growth, stature, and socio-economic status (Acheson and Hewitt, 1954a;

* This value was estimated from our duplicate readings of the films of 189 German children, whose development was retarded (see Acheson, Fowler, and Janes, 1962).
Acheson, 1960; Clements and Pickett, 1952, 1954a, b, 1957, etc.). The finding that skeletal maturation is much less affected by socio-economic status than is growth also bears out earlier work (Greulich, 1951; Acheson and Hewitt, 1954a; Acheson, 1960, etc.). The hypothesis which we set out to test in this study was that, if the environment is the chief reason for this secular increase, then the increase should be greater in a population in which physical circumstances of childhood were considerably improved, than in one in which these circumstances have always been good. Table XI bears out this hypothesis, although the $2 \cdot 3^{\prime \prime}$ excess stature of miners' sons over their fathers is not significantly greater than the between-generation difference of $1.9^{n}$ in the London sample. Tanner (1962) has estimated that the secular increase in stature for males amounts to about $1 \mathrm{~cm}$. per decade, an increase which in round figures amounts to about $1^{n}$ per generation. It is a matter of some interest that, for boys in all three of the socioeconomic groups in this study, the between-generation difference is greater than would be expected on the basis of Tanner's estimate of the secular increase in stature. Tanner $(1962$, p. 150) states that such data as exist indicate that the secular increase in adult stature has probably been less for women than men, and our findings are certainly consistent with this view. Further support comes from a separate analysis of secular increase in stature, for the parents only, in which the regression between stature and date of birth was calculated (see Fig. 4); this also shows that the stature increase has been greater in the Welsh group for males than for females, and that the increase for them is greater than Tanner's mean estimate for Caucasians. There were not enough London parents to permit meaningful regression coefficients to be calculated.

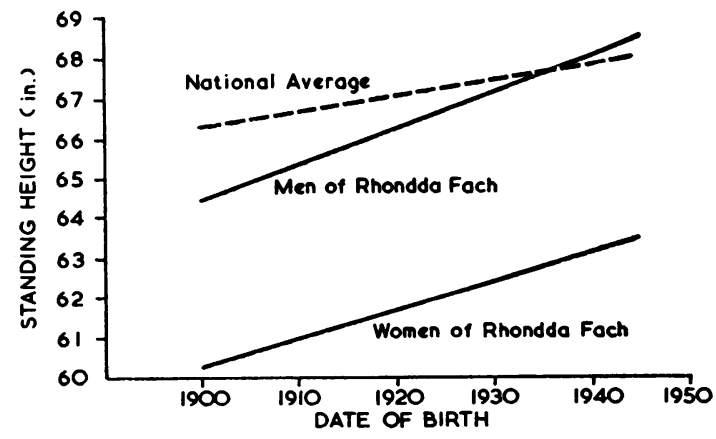

FIG. 4.-Secular trend in adult height, showing stature by date of FIG. 4.-Secular trend in adult height, showing stature by date of
birth for the men and women of the $R$ hondda Fach and the national birth for the men and women of the Rhondda Fach and the national
average (as estimated by Tanner, 1962). It should be borne in mind that loss in stature with ageing will contribute to a minor extent to the smaller stature of the older people. 
Sex Differences in Patterns of Physical DeVELOPMENT

We have taken the view that the differences in physical development between one group and another in this study are, most probably, principally due to environmental influences. It is therefore important to note that in all respects our data show the development of the male to be more labile than that of the female. His rate of skeletal maturation is greater (though not significantly so) in the most prosperous compared to the least prosperous of the groups studied, whereas for girls there is no such difference (Tables V and VII and Fig. 1). The relationship between socio-economic status and growth, whether expressed in terms of height age or of predicted adult height for the sons, or of the stature of the fathers, is more marked than for the mothers or daughters. Moreover the betweengeneration increase in stature which we believe is chiefly due to an all round improvement in the environment of childhood (Acheson and Fowler, 1961 ) is greater, group by group, for the sons than for the daughters.

Our belief that differences in or arising from the environment during childhood will affect the physical development of boys differently from that of girls accords with earlier work in the Oxford Child Health Survey (Acheson and Hewitt, 1954a; Hewitt, Westropp, and Acheson, 1955), and with studies in Guam (Greulich, 1951), Japan (Greulich, Crismon, and Turner, 1953), Belgium (Graffar, Corbisier, van der Berghe, and Asiel, 1961; Graffar, 1962), London (Falkner, 1958; Graffar, 1962), and other places.* All these studies indicate that the male suffers more from environmental vicissitude than the female. However, a re-analysis of data collected by the Department of Experimental Medicine at Cambridge in their studies of children in a German orphanage just after the war (Widdowson and McCance, 1954; Berridge and Prior, 1954) led us to the conclusion that the male also responds more sharply to an improvement in environment than the female (Acheson, Fowler, and Janes, 1962).

Yet these conclusions are at variance with those of some workers. Douglas (Douglas and Blomfield, 1958; Douglas, 1962), in his National Health Survey of 5,388 children, measured the environment in terms of father's occupation, number of siblings, and quality of maternal care. He found that in respect of both growth and health-taking use of the medical services as an index of the latter-girls were more profoundly affected than boys. Of the four

* For further references see Tanner (1962, p. 127). papers which Douglas (1962) cited in support of his findings he leant most heavily on a study by one of the present authors (Acheson and Hewitt, 1954b), stating, quite correctly, that age-for-age in the preschool period there is a much greater difference between girls than between boys in the stature of prosperous American children from the Brush Study compared with a less favoured group of Oxford children. The former were measured between 1932 and 1942, the latter in the immediate post-war era. Neither Douglas nor Acheson and Hewitt took into account the secular increase in the rate of growth. The Brush study was semi-longitudinal and children were recruited at all ages, so that the median year in which the 4- or 5-year-olds were measured would have been 1935; in Oxford most children of this age were seen between 1948 and 1953, a time lapse of 13 to 18 years. Thus, unless the secular increase in growth rate for the two sexes is identical, a direct age-for-age comparison between the two groups is bound to lead to false conclusions.

Tanner (1962), basing his calculations on work from several countries, concluded that the agespecific increase per decade in the stature of children of the age group 5 to 7 years is roughly $1.5 \mathrm{~cm}$; he suggests (p.128) that "boys have probably reacted more [than girls] to whatever factors are responsible for the secular trend". We find the betweengeneration difference in boys to be in the order of $2^{\prime \prime}$ (about $5 \mathrm{~cm}$.), while that in girls is less than $1^{\prime \prime}$; this would suggest that, for these families and for the time period we have studied which spans both the Brush and the Oxford studies, the ratio of secular increase is in the order of $2: 1$ in favour of the male. On the basis of this sex ratio and in round figures, a decade elapsing between the two studies, a population of Oxford boys measured at the same time as the Brush study would have been $2 \mathrm{~cm}$. shorter than they were when the Oxford Child Health Survey was carried out and the girls only $1 \mathrm{~cm}$. less. This correction would imply that at 4 years, the Brush compared with the Oxford boys would have had an advantage of $37.72 \mathrm{~mm}$. compared with the published figure of $16.72 \mathrm{~mm}$.; for girls the hypothetical figure would be $30.07 \mathrm{~mm}$. compared with 20.07 mm. Arguing on a similar basis, at age 5 boys would have a theoretical advantage of $37.81 \mathrm{~mm}$. compared with $17.81 \mathrm{~mm}$., and girls $36.67 \mathrm{~mm}$. compared with $26.67 \mathrm{~mm}$. In other words, if the data are standardized for the trends which occurred during the years which elapsed between the two studies, the differences actually become greater for boys than for girls and thus fall in line with the consensus of other workers. The data are in fact consistent with Tanner's statement (Tanner, 1962) 
that the female shows more power of what Waddington (1957) calls homeorrhesis.*

The question arises then why Douglas's data point in the other direction. Accuracy in standards of measurement of both size and age has greatly increased since the three other papers he cites in support of his views (Greenwood, 1913; Karn and Pearson, 1922; Paton and Findlay, 1926) were written; moreover, they have in common with Douglas the fact that the observations they analyse were made by many persons who were not trained specifically in the techniques of scientific measurement. Douglas's own stature measurements were made "by health visitors, usually at Infant Welfare Centres, though a few [children] were measured at home or at chemists" (Douglas and Blomfield, 1958 , p. 55). Weight records were disregarded because "nearly half the survey children were weighed in their clothes". It is not stated if any were measured in their shoes. Matters such as this would be of little concern if the differing techniques (and the presence or absence of shoes) were randomly distributed between the social classes; in fact very few things are. Certainly attitudes to the medical and nursing professions, to wearing and removing clothes, to style in children's shoes, and even to sons and daughters, differ widely.

The principal findings of this research are a reaffirmation of the fact that the environment has an important effect on the physical development of children in general, but on the male child to a greater extent than the female. We also believe that our data support the view that improvement in the environment is probably the most important single-though not necessarily the only-factor underlying the secular increase in the rate of growth of children and increase of adult height.

\section{SUMMARY}

(1) The study group consisted of 122 families containing both parents and at least one child aged between 2 and 14 years. 24 of these were families of well-to-do London people (X), 9 were of men in professional or commercial employment in South Wales (Y), and 89 were of Welsh coalminers (Z).

(2) There were no significant differences between the rates of skeletal maturation of children in the $X$ and $\mathrm{Z}$ groups, though for boys the $\mathrm{X}$ group was more mature at any age than the $Z$ group.

\footnotetext{
* In the original paper Acheson and Hewitt (1954b) found that, when they compared the growth of the sexes, holding skeletal maturity instead of chronological age constant, the development of the boy was more labile than that of the girl.
}

(3) Two entirely independent techniques were used to show that not only were the $\mathrm{X}$ boys taller at any age than the $\mathbf{Z}$, but that they also grew faster and their adult height was predicted to be greater. For girls growth rates did not differ but the predicted adult height of the $X$ group was greater than that of the $Z$ group. Similar differences were found in the parents' heights.

(4) The between-generation differences in adult stature for the two groups ( $\mathrm{X}$ and $\mathrm{Z}$ ) were also studied, and it was predicted that, for both groups and both sexes (except the well-to-do females), the children would become significantly taller than their parents, the males more so than the females, and that these differences would be greater than those predicted on the basis of the general secular trend for increase in stature. The Y group is intermediate.

(5) Boys are more readily influenced by environmental factors than are girls, both as to their rate of skeletal maturation and to their linear growth.

This survey has been carried out with the help, advice, and material assistance of more people than we can name; it is a great pleasure to express our gratitude to all of them. In particular we must mention Prof. A. L. Cochrane, his own staff of the M.R.C. Epidemiological Research Unit (South Wales), and the staff of the M.R.C. Pneumoconiosis Research Unit, for giving us access to the people of the Rhondda Fach, and for providing us with equipment and wise counsel. Dr. Roy Morley Davies lent us one of his clinics and Mr. William Clarke advised upon and assisted with the radiological aspects of the study. The High Master of St. Paul's School, through the good offices of Dr. John Osborne, graciously agreed to allow us to study the London families on the school premises; Mr. A. B. Cook, the Surmaster, took a particular interest in our work and was most helpful to us. We thank Dr. W. E. Miall for allowing us to use his unpublished data; the Bedford data on stature were collected in collaboration with Prof. W. J. H. Butterfield and his staff. Mr. David Hewitt participated in both planning and field work, and Miss Rosemary Hogg, Dr. Margaret Janes, and Mr. Michael Shaw all helped with the execution of the survey. Miss Anne Mouland prepared the line drawings. The major expense of the research was met by the Medical Research Council and Guy's Hospital Medical School; the analysis was completed with the support of the United States Public Health Service General Research Support Grant No. 1 SO1-FR-05143-01.

\section{REFERENCES}

Acheson, R. M. (1960). In "Human Growth", ed. J. M. Tanner, p. 73. [Symp. Soc. Stud. Hum. Biol., Vol. 3 Pergamon Press, Oxford.

and Fowler, G. B. (1961). Brit. med. J., 2, 957 
Acheson, R. M., Fowler, G. B., Fry, E. I., Janes, M. D., Koski, K., Urbano, P., and Werff ten Bosch, J. J. van der (1963). Hum. Biol., 35, 317.

194,735 .

and Hewitt, D. (1954a). Brit. J. prev. soc. Med., $8,59$.

8, - (1954b). Hum. Biol., 26, 343.

Bayley, B., and Pinneau, S. R. (1952). J. Pediat., 40, 423.

Berridge, F. R., and Prior, K. M. (1954). Spec. Rep. Ser. Med. Res. Counc. Lond., No. 287, p. 119, H.M.S.O., London.

Boyne, A. W. (1960). In "Human Growth", ed. J. M. Tanner, p. 97 [Symp. Soc. Stud. Hum. Biol., Vol. 3] Pergamon Press, Oxford.

- and Leitch, I. (1954). Nutr. Abstr. Rev., 24, 255.

British Medical Journal (1961). Editorial, 2, 502.

Clements, E. M. B., and Pickett, K. G. (1952). Brit. J. soc. Med., 6, 245.

- - (1954a). Brit. J. prev. soc. Med., 8, 99.

$\longrightarrow$ - (1954b). Ibid., 8, 108.

- _- (1957). Ibid., 11, 51.

Cochrane, A. L., Cox, J. G., and Jarman, T. F. (1952). Brit. med. J., $2,843$.

-, (1955). Ibid., 1, 371.

Doll, R. (1959). In "Medical Surveys and Clinical Trials", ed. L. J. Witts, p. 75. Oxford University Press, London. Douglas, J. W. B. (1962). Mod. Probl. Paediat., 7, 178.

and Blomfield, J. M. (1958). "Children under Five". Allen and Unwin, London.

Falkner, F. (1958). Arch. Dis. Childh., 33, 1.

(1960). Mod. Probl. Paediat., 5, 70.

Graffar, M. (1962). Ibid., 7, 159.

$\longrightarrow$, Corbisier, J., van der Berghe, F., and Asiel, M. (1961). Arch. belges Méd. soc., 19, 77.

Greenwood, A. (1913). "The Health and Physique of School Children", Ratan Tata Foundation, London School of Economics. King, London.
Greulich, W. W. (1951). Amer. J. phys. Anthrop., n.s. 9, 55.

$\longrightarrow$, Crismon, C. S., and Turner, M. L. (1953). J. Paediat., 43, 121.

- and Pyle, S. I. (1959). "Radiographic Atlas of Skeletal Development of the Hand and Wrist", 2nd ed. Stanford University Press, Stanford.

Hewitt, D., and Acheson, R. M. (1961). Amer. J. phys. Anthrop., n.s. 19, 333.

, Westropp, C. K., and Acheson, R. M. (1955). Brit. J. prev. soc. Med., 9, 179.

Hulse, F. S. (1957). Arch. suisses Anthrop. gén., 22, 103.

Karn, M. N., and Pearson, K. (1922). "Study of the Data provided by a Baby-clinic in a Large Manufacturing Town" [Drapers' Company Research Memoirs. Studies in National Deterioration, X]. Cambridge University Press, London.

Martin, W. J. (1949). "The Physique of Young Adult Males", Med. Res. Counc. Memo., No. 20. H.M.S.O., London.

Miall, W. E., and Oldham, P. D. (1955). Clin. Sci., 14, 459.

- - - (1963). Brit. med. J., 1, 75.

Paton, D. N., and Findlay, L. (1926). Spec. Rep. Ser. Med. Res. Counc. Lond., No. 101. H.M.S.O., London.

Tanner, J. M. (1958). In "Modern Trends in Paediatrics (Second Series)", ed. A. Holzel and J. P. M. Tizard, p. 325. Butterworth, London.

(1962). "Growth at Adolescence", 2nd ed. Blackwell Scientific Publications, Oxford.

__ and Whitehouse, R. H. (1959). Lancet, 2, 1086.

Todd, T. W. (1937). "Atlas of Skeletal Maturation" Mosby, St. Louis.

Waddington, C. H. (1957). "The Strategy of the Genes" pp. 32, 43. Allen and Unwin, London.

Widdowson, E. M., and McCance, R. A. (1954). Spec. Rep. Ser. Med. Res. Counc. Lond., No. 287. H.M.S.O., London. 